\title{
PEMBELAJARAN INKUIRI BERBANTUAN MEDIA VIRTUAL LABORATORY SIMULATION: KETERAMPILAN BERPIKIR
}

\author{
Farida Nur Kumala ${ }^{1,}{ }^{*}$, Hartatik ${ }^{2}$ \\ ${ }^{1}$ Universitas Kanjuruhan Malang \\ 2 Universitas Kanjuruhan Malang
}

\begin{abstract}
Abstrak
Tujuan penelitian ini adalah untuk meningkatkan keterampilan berpikir mahasiswa melalui penerapan pembelajaran inkuri berbantuan media virtual laboratory simulation. Penelitian ini menggunakan penelitian tindakan kelas (PTK) dengan subyek penelitian adalah mahasiswa kelas B2014. Instrumen yang digunakan pada penelitian ini adalah instrumen lembar observasi dan angket pelaksanaan pembelajaran. Kemampuan berpikir pada penelitian ini diukur menggunakan soal tes yang disesuaikan dengan ranah kognitif C1-C6. Hasil penelitian menunjukkan bahwa penerapan pembelajaran inkuiri berbantuan media virtual laboratory simulation terdiri dari beberapa tahapan utama yaitu orientasi masalah, pengembangan hipotesis, pengumpulan data, analisis data, pengujian hipotesis, dan penarikan kesimpulan. Berdasarkan hasil data penelitian diketahui keterlaksanaan pembelajaran inkuri meningkat dari siklus I sebesar $75 \%$ menjadi $85 \%$ pada siklus II. Berdasarkan hasil penelitian pembelajaran inkuri berbantuan media virtual laboratory simulation dapat meningkatkan keterampilan berpikir mahasiswa yang ditunjukkan dengan peningkatan nilai pada siklus I 85 dan pada siklus II ditunjukkan rata-rata 92.
\end{abstract}

\author{
Keywords: \\ Inkuiri, \\ Media Virtual Laboratory \\ Keterampilan Berpikir
}

\section{Pendahuluan}

Pendidikan merupakan salah satu kebutuhan hidup manusia dalam usahanya untuk mempertahankan hidup dan mengembangkan diri masyarakat. Melalui pendidikan manusia akan terbebas dari keterbelakangan, kebodohan, dan bahkan terbebas dari kemiskinan. Pendidikan yang berkualitas akan menghasilkan sumber daya manusia yang berkualitas pula, sehingga mampu mengembangkan kemampuan berpikir agar sadar ilmu pengetahuan teknologi dan seni (IPTEKS), serta mampu mengikuti dan memanfaatkan perkembangan tersebut (Metaputri, 2016). Dewasa ini dunia berada pada abad 21, yaitu suatu era yang ditandai oleh perkembangan ilmu pengetahuan dan teknologi (iptek) yang berlangsung secara eksponensial. Untuk dapat mengikuti kemajuan iptek yang begitu cepat, melek sains menjadi kebutuhan setiap orang. Melek sains juga merupakan kebutuhan penting di dunia kerja. Kebanyakan pekerjaan dan tugas-tugas pekerjaan membutuhkan keterampilan tingkat tinggi yang mempersyaratkan masyarakat yang dapat belajar, bernalar, berpikir kreatif, membuat keputusan, dan memecahkan masalah (Suma, 2010). Salah satunya pembelajaran di perguruan tinggi.

Sistem pembelajaran diperguruan tinggi menggunakan sistem pembelajaran untuk orang dewasa yang lebih menekankan pada kemandirian mahasiswa. Kemandirian sebagai hasil dari menimba pengetahuan dan pengalaman yang dimilikinya menjadi tolak aktivitas belajar orang dewasa. Inisitaif lebih banyak datang dari diri sendiri daripada stimulus dari luar. Oleh karena itu, Pendekatan konstruktivis lebih relevan dibandingkan pembelajaran behaviouristik yang menekankan stimulus respon Knowles dalam Kopertis VII (2014)

Pembelajaran konstruktivistik menekankan pentingnya inisiatif dan dorongan intrinsik mahasiswa. Pembelajaran seperti ini mensyaratkan dosen untuk mengenal self-concept mahasiswa, tidak saja dalam kelompok tetapi juga secara individu. Berdasarkan hal tersebut, dosen disyaratkan tidak hanya mampu berkomunikasi secara efektif terhadap mahasiswa namun kemampuan memilih strategi dan media yang tepat dalam proses pembelajaran.

Berdasarkan hasil observasi pada pembelajaran matakuliah IPA SD di program studi Pendidikan Guru Sekolah Dasar UNIKAMA diketahui, lebih sering menggunakan metode ceramah dan presentasi. 
Metode ini membuat mahasiswa belajar masih abstrak karena konsep hanya disajikan dalam bentuk kata - kata bukan suatu proses, akibatnya mahasiswa pasif menerima pembelajaran, karena hanya kelompok yang presentasi yang lebih aktif. Pembelajaran belum diarahkan pada proses siswa dapat aktif dan kreatif dalam mengkonstruksi pengetahuan yang didapatkannya, sehingga pembelajaran dirasa kurang bermakna dan kurangnya pemahaman pada mahasiswa. Akibat hal tersebut, hasil belajar kognitif peserta didik hanya 25\% mahasiswa yang mendapatkan nilai diatas 75 . Fenomena ini menunjukkan hal yang menghawatirkan sebab, mahasiswa PGSD adalah calon guru yang nantinya harus menanamkan konsep kepada siswanya.

Menanggapi hal tersebut, penggunaan metode presentasi dan ceramah tidak selamanya tepat digunakan walaupun dalam tataran mahasiswa khususnya pembelajaran konsep IPA dan karakteristik IPA sendiri lebih banyak menjelaskan tentang alam sekitar yang bersifat nyata. Secara umum IPA merupakan kumpulan pengetahuan yang sistematis dan tersusun secara teratur, berlaku umum, dan berupa kumpulan data hasil observasi dan eksperimen (Carin dan Sund, 1993). IPA memiliki 4 unsur utama yang terdiri dari sikap, proses, produk dan aplikasi.

Berdasarkan 4 unsur IPA yang telah disebutkan, pembelajaran IPA seharusnya disajikan tidak hanya melalui hafalan seperangkat pengetahuan fakta, konsep dan prinsip saja, namun IPA adalah suatu proses. Sehingga dalam melaksanakan pembelajarannya, IPA harus disajikan melalui pembelajaran yang bermakna. Pemerintah telah mengatur proses pembelajaran IPA, pembelajaran IPA di sekolah sebaiknya (Depdiknas, 2009): memberikan pengalaman kepada peserta didik, menanamkan pada peserta didik pentingnya pengamatan empiris dalam menguji hipotesis, latihan berpikir kuantitatif pada masalah nyata yang berkaitan dengan peristiwa alam dan memperkenalkan dunia teknologi melalui kegiatan kreatif.

Salah satu cara untuk mengatasi permasalahan tersebut adalah dengan menggunakan pembelajaran inkuiri. Model pembelajaran inkuiri memberi solusi tentang pembelajaran yang berpusat pada siswa (student centred) (Sudiasa, 2012). Model pembelajaran Inkuiri adalah suatu rangkaian kegiatan belajar yang melibatkan secara maksimal seluruh kemampuan siswa untuk mencari dan menyelidiki secara sistematis, kritis, logis, analitis, sehingga mereka dapat merumuskan sendiri penemuannya dengan penuh percaya diri (Gulo, 2000). Pembelajaran menggunakan model inkuiri mendorong pemahaman materi secara mendalam dan mengembangkan pemikiran siswa, efektif untuk meningkatkan motivasi siswa, karena tingkat keterlibatan siswa tinggi (Enggen dan Kauchak, 2012), ditambahkan Alameddin \& Ahwal, 2016; menyatakan bahwa pembelajaran inkuiri dapat meningkatkan prestasi siswa dan siswa menikmati selama pembelajaran berlangsung (Suduc, et.al, 2015).

Inkuiri digambarkan sebagai proses aktif untuk mengamati, mengajukan pertanyaan, merencanakan penyelidikan, meninjau kembali apa yang sudah diketahui berdasarkan bukti pengamatan/ kegiatan eksperimen, mengumpulkan data, menganalisa data dan menjawab pertanyaan serta mengkomunikasikan hasil (Arslan, 2013; Pedaste et.al; 2015)

Namun, pembelajaran inkuiri juga memiliki keterbatasan seperti pada konsep - konsep yang abstrak seperti energi, listrik, maupun partikel yang tidak dapat dilihat secara visual oleh peserta didik. Selain itu pada kenyataanya pembelajaran menggunakan media nyata dan praktikum nyata tidak selalu dapat dilakukan dalam kegiatan perkuliahan, oleh karena keterbatasan waktu, alat dan tempat yang dimiliki. Dalam mengatasi hal tersebut dapat digunakan bantuan media virtual laboratory.

Virtual Laboratory adalah serangkaian alat-alat laboratorium yang berbentuk perangkat lunak (software) komputer berbasis multimedia interaktif, yang dioperasikan dengan komputer yang dapat mensimulasikan kegiatan di laboratorium dan juga penggambaran konsep-konsep abstrak. Pengembangan laboratory virtual ini diharapkan dapat menyelesaikan permasalahan belajar khususnya keabstrakan pada suatu konsep yang dialami oleh peserta didik.

Salah satu virtual laboratory contohnya adalah simulasi interaktif yang dikembangkan oleh Universitas di Colorado America. Simulasi Interaktif yang dikembangkan adalah simulasi interaktif PhET. Program simulasi interaktif PhET ini berisi lengkap konsep IPA seperti fisika, kimia dan biologi. Konsep konsep ini secara nyata menggambarkan konsep yang abtrak dan tidak dapat dilihat misalnya konsep partikel, energi dan listrik. Sehingga melalui program ini, peserta didik tidak kesulitan untuk memahami suatu materi.

Secara umum manfaat yang didapatkan melalui pembelajaran multimedia dalam bentuk virtual laboratory adalah proses pembelajaran menjadi lebih menarik, jumlah waktu mengajar dapat dikurangi, kualitas belajar dapat ditingkatkan dan proses belajar mengajar dapat dilakukan di mana saja dan kapan saja (Reismeiyanto, 2008).

Berdasarkan latar belakang yang telah dipaparkan sebelumnya, maka dilakukan penelitian dengan judul "Pembelajaran Inkuiri Berbantuan Media Virtual Laboratory Simulation : Keterampilan Berpikir" yang bertujuan untuk meningkatkan keterampilan berpikir mahasiswa melalui penerapan pembelajaran inkuri berbantuan media virtual laboratory simulation. 


\section{Metode Penelitian}

Penelitian ini merupakan penelitian tindakan kelas (PTK) dengan subyek penelitian adalah mahasiswa PGSD angkatan tahun 2014 B sebanyak 22 mahasiswa. Instrumen yang digunakan pada penelitian ini adalah lembar observasi yang digunakan untuk melakukan observasi keterlaksanaan pembelajaran, aktivitas mahasiswa dan soal tes untuk mengukur keterampilan berpikir mahasiswa.

Pada penelitian ini keterampilan berpikir diukur menggunakan ranah C1- C6 mengunakan indikator sebagai berikut (Anderson dan Krathwol, 2011) pada tabel 1. Teknik analisis data yang digunakan pada penelitian ini adalah teknik analisis data kualitatif dan kuantitatif deskriptif. Teknik analisis data kualitiatif menggunakan teknik analisis data Miles dan Huberman yang terdiri dari pengumpulan data, reduksi data, penyajian data dan penyimpulan, untuk teknik analisis data kuantitatif deskriptif diukur untuk mengukur rata- rata keterampilan berpikir mahasiswa dengan rumus sebagai berikut:

$$
\text { Rata-rata } \frac{: \varepsilon \text { nilai seluruh mahasiswa }}{\text { sjumlah mahasiswa }}
$$

Tabel 1. Tabel Domain Kognitif Bloom

\begin{tabular}{lll}
\hline No & $\begin{array}{l}\text { Domain } \\
\text { Kognitif }\end{array}$ & \multicolumn{1}{c}{ Kategori Kemampuan } \\
\hline 1 & C1 & Mengingat: mengambil pengetahuan dari memori jangka panjang \\
\hline 2 & C2 & $\begin{array}{l}\text { memahami yaitu mengkonstruksi makna dari materi pembeljaaran, termasuk apa } \\
\text { yang diucapkan, ditulis dan digambar }\end{array}$ \\
\hline 3 & C3 & $\begin{array}{l}\text { mengaplikasikan yaitu menerapkan atau menggunakan suatu prosedur dalam } \\
\text { keadaan tertentu }\end{array}$ \\
\hline 4 & C4 & $\begin{array}{l}\text { menganalisa merupakan kegiatan untuk memecah-mecah materi menjadi bagian- } \\
\text { bagian nnya dan menentukan hubungan antar bagian itu dan keseluruhan struktur } \\
\text { atau tujuan }\end{array}$ \\
\hline 5 & C5 & $\begin{array}{l}\text { mengevaluasi yaitu mengambil keputusan berdasarkan krteria dan atau } \\
\text { pertimbangan }\end{array}$ \\
\hline 6 & C6 & $\begin{array}{l}\text { mencipta yaitu memadukan bagian - bagian untuk membentuk sesuatu yang baru } \\
\text { dan koheren atau untuk membuat sesuatu produk yangg orisinal. }\end{array}$ \\
\hline
\end{tabular}

\section{Hasil Dan Pembahasan}

Berdasarkan penelitian yang telah dilakukan sebelumnya dapat diketahui bahwa pelaksanaan pembelajaran menggunakan model pembelajaran inkuiri dapat mengembangkan aktivitas, minat dan kemampuan berpikir mahasiswa yang ditunjukkan pada tabel 2.

Tabel 2. Hasil pada siklus I dan II

\begin{tabular}{cccc}
\hline No & Keterlaksanaan Pembelajaran & Aktivitas & Kemampuan Berpikir \\
\hline 1 & $75 \%$ & $70 \%$ & 85 \\
\hline 2 & $85 \%$ & $75 \%$ & 90 \\
\hline
\end{tabular}

Berdasarkan tabel 2 diketahui bahwa terdapat peningkatan hasil pada siklus I ke siklus II. Pada aspek keterlaksanaan pembelajaran terdapat peningkatan 10\%, aktivitas meningkat 5\% dan kemampuan berpikir juga telah mencapai peningkatan 5 poin. Hal ini disebabkan model pembelajaran inkuri memberikan kesempatan dan kewajiban pada pserta didik untuk selalu aktif berpikir dan bertindak dalam belajar. Trianto (2009) menjelaskan bahwa model pembelajaran inkuri memberikan kesempatan siswa untuk selalu aktif dalam melakukan pembelajaran, mahasiswa melaksanakan pembelajaran secara mandiri dan sedikit bantuan dari dosen. Pembelajaran inkuiri dirancang untuk mengajak siswa secara langsung kedalam proses ilmiah dan dapat meningkatkan keterampilan siswa. 
Secara detail kemampuan berpikir mahsiswa sesuai dengan domain C1 - C6 ditunjukkan pada tabel 3.

Tabel 3. Tabel Sebaran Kemampuan Berpikir Mahasiswa

\begin{tabular}{ccc|c}
\hline \multirow{2}{*}{ No } & \multirow{2}{*}{ Domain Kognitif } & \multicolumn{2}{c}{ Persentase } \\
\cline { 2 - 4 } & & Siklus I & Siklus II \\
\hline 1 & C1 & $85 \%$ & $100 \%$, \\
\hline 2 & C2 & $81 \%$, & $100 \%$, \\
\hline 3 & C3 & $95 \%$ & $80 \%$, \\
\hline 4 & C4 & $95 \%$ & $90 \%$, \\
\hline 5 & C5 & $90,5 \%$, & $100 \%$. \\
\hline 6 & C6 & $80 \%$ & $80 \%$ \\
\hline
\end{tabular}

Berdasarkan tabel tersebut dapat diketahui bahwa terdapat peningkatan keterampilan berpikir mahasiswa melalui penerapan pembelajaran inkuri berbantuan media virtual laboratory simulation pada siklus I dan siklus II. Peningkatan hasil secara garis besar disebabkan oleh pelaksanaan pembelajaran inkuri yang telah berjalan beberapa kali, sehingga mahasiswa telah terbiasa dengan langkah pembelajaran inkuiri. Namun berdasarkan tabel 3 juga diketahui penurunan aspek C3 dan C4, hal ini kemungkinan disebabkan oleh tingkat bobot soal yang berbeda pada setiap pertemuan.

Pada penelitian ini terdiri dari siklus I dan siklus II yang menerapkan beberapa langkah inkuri yakni: orientasi masalah, pengembangan hipotesis, pengumpulan data melalui eksperimentasi dan pengamatan, analisisis masalah, pengujian hipotesis dan penarikan kesimpulan.

Tahapan pada pembelajaran inkuri diawali dengan orientasi masalah, pada tahap ini mahasiswa disajikan suatu permasalahan atau pertanyaan untuk mengembangkan kemampuan berpikir dan mengarahkan pada apersepsi mahasiswa. Pertanyaan yang diberikan harus dijawab oleh mahasiswa sesuai dengan pengetahuan yang dimilikinya. Orientasi masalah dapat mengembangkan kemampuan berpikir mahasiswa. Pemberian pertanyaan akan dapat mengembangkan kemampuan berikpikir pada seseorang (Jansen, 2011).

Tahapan kedua pada tahapan inkuiri adalah tahapan mengembangkan hipotesis. Trianto (2009) menyatakan bahwa hipotesis merupakan suatu jawaban sementara atau solusi permasalahan yang dapat diuji dengan data. Pembuatan hipotesis pada peserta didik dapat mengembangkan daya analisis peserta didik terhadap kejadian disekitar pesreta didik dan dapat mencari hubungan antara variabel yang terikat didalamnya. Berhipotesis juga dapat mengajak siswa untuk membayangkan kondisi yang sebenaranya dan mengidentifikasi komponen-komponen yang berada pada kondisi tertentu (Joice, 1992). Kegiatan berhhipotesis pada siklus I dituliskan pada lembar pekerjaan mahasiswa, pada tahapan tersebut mahasiswa hanya membayangkan kejadian dan kemungkinan yang akan terjadi, pada tahapan ini mahasiswa masih mnegalami kesulitan karena masih belum terbiasa dan tidak ada visualisasi untuk menjelaskan kejadian yang berlangsung, namun ketika siklus II kegiatan berhipotesis dirasa lebih mudah karena mahasiswa diberikan visualisasi dengan menggunakan media virtual simulation pHET/ virtual laboratory.

Virtual labratory (Virtual Labs) merupakan salah satu multimedia yang berisi simulasi pembelajaran yang dapat digantikan dengan simulasi komputer (virtual labs). Simulasi komputer dalam pembelajaran IPA merupakan simulasi eksperimen - eksperimen IPA yang berada di komputer yang dapat diakses melalui internet (Wisudawati dan Eka, 2013). Simulasi virtual memberikan banyak kebebasan pada siswa, mereka dapat memanipulasi variabel variabel yang berkaitan dengan eksperimen yang sedang dilakukan dan sekaligus dapat melihat bagaimana pengaruh perubahan suatu variabel terhadap variabel lainnya (Sinaga, 2011).

Tahapan inkuri yang ketiga dilanjutkan dengan merancang percobaan, pada tahapan ini mahasiswa hanya diberikan LKS yang berisikan alat dan bahan dan instruksi untuk merancang secara mandiri percobaan. Hal ini dilaksanakan dengan harapan mahasiswa mampu melakukan percobaan dengan cara yang berbeda-beda namun untuk mendapatkan hasil yang sama.

Konsep pembelajaran dengan mahasiswa merancang sendiri percobaan dianggap sebagai proses pembelajaran menggunakan inkuri bebas/ mandiri yang dimodifikasi. (Sanjaya, 2008) inkuiri bebas dimodifikasi merupakan pendekatan ini siswa tidak dapat memilih atau menentukan masalah untuk diselidiki secara sendiri, namun siswa yang belajar dengan pendekatan ini menerima masalah dari gurunya untuk dipecahkan dan tetap memperoleh bimbingan, namun bimbingan yang diberikan lebih sedikit dari Inkuiri terbimbing dan tidak terstruktur. 
Perancangan mandiri oleh peserta didik selama kegiatan praktkum dirasa dapat meningkatkan kreativitas mahasiswa dalam mengatasi beberapa masalah, tanpa terpaku pada satu arahan. Joyce dan Weil (1992) menyatakan bahwa inkuri dapat meningkatkan pemahaman sains, berpikir kreatif. Kreatif didefiniskan Munandar (1990) sebagai kemampuan berdasarkan data atau informasi yang teresedia untuk menemukan banyak kemungkinan jawaban terhadap suatu masalah yang menekankan pada kuantitas, ketepatgunaan dan keberagaman jawaban.

Kegiatan selanjutnya dalam pembelajaran inkuri adalah melakukan percobaan untuk memperoleh informasi dan mengumpulkan data, kegiatan memperoleh informasi dilakukan oleh mahsiswa melalui kegiatan pengamatan ataupun eksperimen yang idseusiakan dengan hipotesis yang telah diberikan sebelumnya. Mahasiswa mengumpulkan data hasil dari rancangan praktikum yang telah dilakukan. Kegiatan mengumpulkan data menjadikan pembelajaran bermakna karena mahasiswa dpat mencari dan mengkonstruksi ilmu melalui pengalamannya sendiri. Kegiatan pengumpulan informasi mengacu pada pembelajaran kosntrukstivis. Pendekatan kosntruktivis menekanakn pentingnya siswa untuk membangun sendiri pengetahuan mereka lewat kegiatan aktif pembelajaran (Trianto, 2009). Selain hal tersebut pada tahap ini dapat memupuk mahasiswa menjadi pebelajar mandiri.

Tahapan kelima pada pembelajaran inkuri yaitu menguji hipotesis, analisa data dan diakhiri dengan kegiatan menyimpulkan. Siswa bertanggung jawab menguji hipotesis yang telah dirumuskan dengan menganalisis data yang telah diperoleh. Kemampuan menganalisa masuk pada tahapan $\mathrm{C} 4$ atau pada kemampuan berpikir tingkat tinggi. Menganalisis diartikan suatu kegiatan untuk memecah-mecah materi menjadi bagian-bagian penyusunnya dan menentukan hubungan antar bagian itu dan keseluruhan struktur atau tujuan (Anderson dan Krathwol, 2011). Hasil analisis selanjutnyaa dilakukan uji hipotesis untuk mengevaluasi proses berpikir mereka sendiri dan keterampilan penyelidikan yang digunakan sebelumnya (Trianto, 2009).

Hasil penelitian ini didukung oleh hasil penelitian Marheni, dkk (2014) mengenai Studi Komparasi Model Pembelajaran Inkuiri Terbimbing dan Model Pembelajaran Inkuiri Bebas Terhadap Hasil Belajar dan Keterampilan Proses Sains Siswa Pada Pembelajaran Sains SMP. Dengan hasil penelitian siswa yang belajar dengan menggunakan model pembelajaran Inkuiri Terbimbing memiliki rata-rata sebesar 32,61 dengan standar deviasi 10,08. Sedangkan untuk model pembelajaran inkuiri bebas memiliki rata- rata sebesar 28,67 dengan standar deviasi sebesar 8,77. Hal ini mengindikasikan bahwa dalam pencapaian keterampilan proses sains siswa untuk siswa yang mengikuti model pembelajaran Inkuiri Terbimbing memberikan hasil yang lebih baik dibandingkan dengan siswa untuk siswa yang mengikuti model pembelajaran inkuiri bebas.

Hasil penelitian ini juga didukung oleh hasil penelitian Hermawati (2012) yang menyatakan bahwa, siswa dengan minat belajar yang rendah akan berpengaruh pada proses pembelajaran yang berlangsung. Ketiadaan minat terhadap pelajaran menjadi penyebab kurang bersemangatnya siswa dalam melakukan aktivitas pembelajaran.

Berdasarkan uraian di atas memberikan gambaran bahwa penerapan pembelajaran inkuiri Berbantuan Media Virtual Laboratory Simulation telah mampu memberikan kontribusi yang positif dalam meningkatkan keterampilan berpikir mahasiswa.

\section{Simpulan dan Saran}

Berdasarkan penelitian yang telah dilaksanakan diketahui bahwa penelitian terdiri dari dua siklus dengan menerapkan model pembelajaran inkuri berbantuan media virtual simulation pHET yang terdiri dari langkah pembelajaran orientasi masalah, pengembangan hipotesis, pengumpulan data melalui eksperimentasi dan pengamatan, analisisis masalah, pengujian hipotesis dan penarikan kesimpulan. Keterlaksanaan pembelajaran meningkat dari $75 \%$ pada siklus I menjadi $85 \%$ pada siklus II. Berdasarkan hasil penelitian pembelajaran inkuri berbantuan media virtual laboratory simulation dapat meningkatkan keterampilan berpikir mahasiswa yang ditunjukkan dengan peningkatan nilai pada siklus I 86 dan pada siklus II ditunjukkan rata-rata 92.

\section{Daftar Pustaka}

Alameddin M.M. and. Ahwal, H.W. (2016). Inquiry Based Teaching in Literature Classrooms (Procedia Social and Behavioral Sciences 232, 2016 ) pp. $332-337$

Arslan. (2014). Transition between Open and Guided Inquiry Instruction(Procedia - Social and Behavioral Sciences 141,2014$)$, pp.407- 412

Anderson dan Krathwol. (2010). Kerangka Landasan Untuk Pembelajaran, Pengajaran dan Asesmen. Penerjemah: Agung Prihantoro. Yogyakarta: Pustaka Pelajar. 
Depdiknas. (2009). Model Pembelajaran Terpadu IPA. Jakarta : Badan penelitian dan Pengembangan Pendidikan Nasional Pusat Kurikulum.

Enggen dan Kauchak.( 2012). Strategi dan Model Pembelajaran. Edisi Keenam. Terjemahan: Satrio Wahono. Jakarta: Indeks

Fasilitator Pelatihan Pekerti-AA Kopertis WilayahVII. (2014). Modul Pelatihan Pengembangan Keterampilan Dasar Teknik Instruksional (PEKERTI). Surabaya: Koordinasi PTS Wilayah VII.

Jensen, E. (2008). Pemelajaran Berbasis Otak Paradigma Pengajaran Baru. Terjemahan Molan. 2011. Jakarta: Indeks.

Hermawati, Manik IW. 2012. "Pengaruh Model Pembelajaran Inkuiri terhadap Penguasan Konsep Biologi dan Sikap Ilmiah Siswa SMA Ditinjau dari Minat Belajar Siswa". Tesis (tidak diterbitkan) Program Studi Pendidikan Sains Pascasarjana Universitas Pendidikan Ganesha.

Marheni, dkk. 2014. "Studi Komparasi Model Pembelajaran Inkuiri Terbimbing dan Model Pembelajaran Inkuiri Bebas Terhadap Hasil Belajar dan Keterampilan Proses Sains Siswa Pada Pembelajaran Sains SMP”. Tersedia pada http://pasca.undiksha.ac.id/ejournal/index.p hp/jurnalipa/article/viewFile/1286/988 (diakses pada 15 Januari 2016).

Metaputri, Ni Kadek ,Ni Nym. Garminah. 2016. Pengaruh Model Pembelajaran Inkuiri Terbimbing Dan Minat Belajar Terhadap Keterampilan Proses Sains Pada Siswa Kelas IV SD. Jurnal Pendidikan dan Pengajaran, Universitas Pendidikan Ganesha, Jilid 49, Nomor 2, Juli 2016, hlm.89-97.

Pedaste, M et.al. (2015). Phases Of Inquiry-Based Learning: Definitions And The Inquiry Cycle, (Educational Research Review 14, 2015) pp. 47-61

Sanjaya, $\quad$ W. (2008). Strategi Pembelajaran Berorientasi Standar Proses Pendidikan. Kencana Prenada Media Group. Jakarta

Sinaga. (2011). Penerapan Simulasi dan Interactive Virtual Laboratory Pada Pembelajaran Fisika Modern untuk Meningkatkan Pemahaman Konsep Radioaktivitas Inti, Reaksi Inti dan Aplikasinya. Prosiding Seminar Jurusan Pendidikan Fisika FPMIPA UPI

Sudiasa, I Wayan. 2012. Pengaruh Model Pembelajaran Inkuiri Dan Kemampuan Numerik Terhadap Hasil Belajar Matematika. Jurnal Pendidikan dan Pengajaran, Universitas Pendidikan Ganesha, Jilid 45, Nomor 3, Oktober 2012, hlm.263-27.

Suduc et.al. (2015). Inquiry Based Science Learning in Primary Education (Procedia - Social and Behavioral Sciences 205, 2015 ) pp. $474-479$

Suma, Ketut. 2010. Efektivitas Pembelajaran Berbasis Inkuiri Dalam Peningkatan Pengusaan Konten Dan Penalaran Ilmiah Calon Guru Fisika. Jurnal Pendidikan dan Pengajaran, Universitas Pendidikan Ganesha ,Jilid 43, Nomor 6, April 2010, hlm.47 - 5

Trianto. (2009). Mendesain Model Pembelajaran Inovatif-Progresif, Konsep, Landasan dan Implementasinya pada KTSP. Jakarta: Kencana Prenada Media Group.

Wisudawati, A dan Sulistyowati, E. (2014). Metodologi Pembelajaran IPA. Bumi Aksara. Jakarta 